特集 第 23 回 獣医疫学会学術集会

国際シンポジウム“食の安全確保のための疫学研究と科学的リスク評価”

\title{
アジアにおける高病原性鳥インフルエンザの疫学
}

筒井俊之*

動物衛生研究所 疫学研究チーム

\section{Epidemiology of Highly Pathogenic Avian Influenza in Asia}

\author{
Toshiyuki TSUTSUI
}

Epidemiological Research Team, National Institute of Animal Health

\section{Summary}

Highly pathogenic avian influenza caused by $\mathrm{H} 5 \mathrm{~N} 1$ strains has spread in Asian region in recent years. This disease has seriously affected poultry and other related industries. There are several constraints on the disease control in this region. However, activities have been enhanced to overcome these constraints under the cooperation with international organizations and donor countries. Development of harmonized control strategies is required taking account of active movements of people and commodities across the country borders in this region.

2003 年以来，H5N1 亜型ウイルスによる高病原性鳥イ ンフルエンザ（HPAI）がアジアを中心とする国々で発生 している。アメリカ, オセアニアでは発生が認められてい ないが，アジアからヨーロッパ，アフリカにかけて広く発 生が認められている。特に, アジア地域では他の地域に比 ベて発生報告数が多く, 2007 年 11 月初めまでに 4,000 件 を超える発生が報告されている（図 1)。2003 年からの総 報告数を見るとベトナム，夕イが多く，インドネシア， ミャンマー, 中国と続いている。アジアではこの疾病に よってこれまで 2 億羽以上の家きんが殺処分され, 地域 の家きん産業に深刻な打撃を与えている。また，この疾病 の発生があった国からの家きん肉の輸入は制限されるた め, これまで家きん肉の主要輸出国であったタイや中国 はその国際市場の喪失によって, 甚大な経済的被害を 被った。さらに, H5N1 ウイルスの感染は家きんや野鳥だ けにとどまらず，東南アジアを中心としてこのウイルス によるヒトでの感染・死亡が報告されている（図 2)。な かでも，インドネシアでは死亡数が多く，11月初めまで

\section{連絡先 : 筒井俊之*}

動物衛生研究所疫学研究チーム

干305-0856 茨城県つくば市観音台3-1-5

Tel : 029-838-7769; Fax : 029-838-7769

E-mail : tsutsui@affrc.go.jp
に 90 人の死亡が確認されている。 H5N1 ウイルスがヒト からヒトへの感染能力を獲得した場合，ヒトの間でイン フルエンザの大流行を引き起こす可能性があるため, ウ イルス性状の変化について世界中で注目し，警戒してい る状況にある。

アジア地域で HPAI の発生が多い理由の一つとして, 鶏とアヒルの飼養羽数が多いことが挙げられる（図 3）。 アジア地域のなかでも中国では 42 億羽の鶏が飼養されて おり，その人口の多さとともに他の国に比べて抜きんで ているが，インドネシアの 11 億羽をはじめ, 東南アジア 地域の国々でも相当数の鶏が飼養されている。これらの 国では小規模の飼育農家も多く，自家消費用として少数 の鶏を放し飼い飼育することも一般的に行われている。 また，アヒルについても中国を筆頭にベトナムやインド ネシアなど東南アジア地域で屯多く飼養されている。東 南アジア地域ではこれらのアヒルの飼育形態は水田での 稲作と結びついていることが多い。

FAO や OIE が実施した最近のアジア各国での HPAI の発生状況に関する分析によれば，発生状況に応じてこ れらの国をいくつかに分類することができる。過去に流 行があり，現在常在化に移行している国として，インドネ シアと中国 (一部地域) が挙げられている。両国ともワク チン接種を基本とする防疫措置を講じているがその後も 


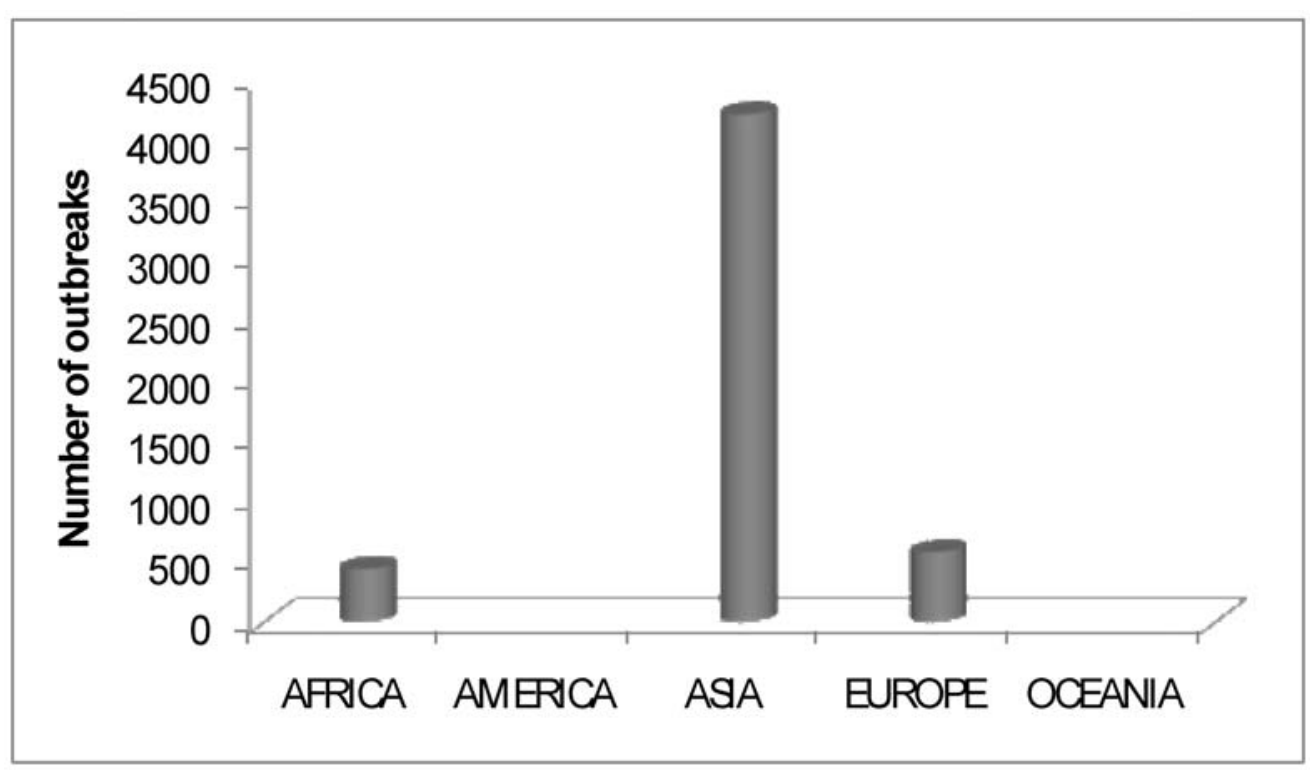

図 12003 年以降の地域別トリインフルエンザ（H5N1）の発生数（出典 : OIE）

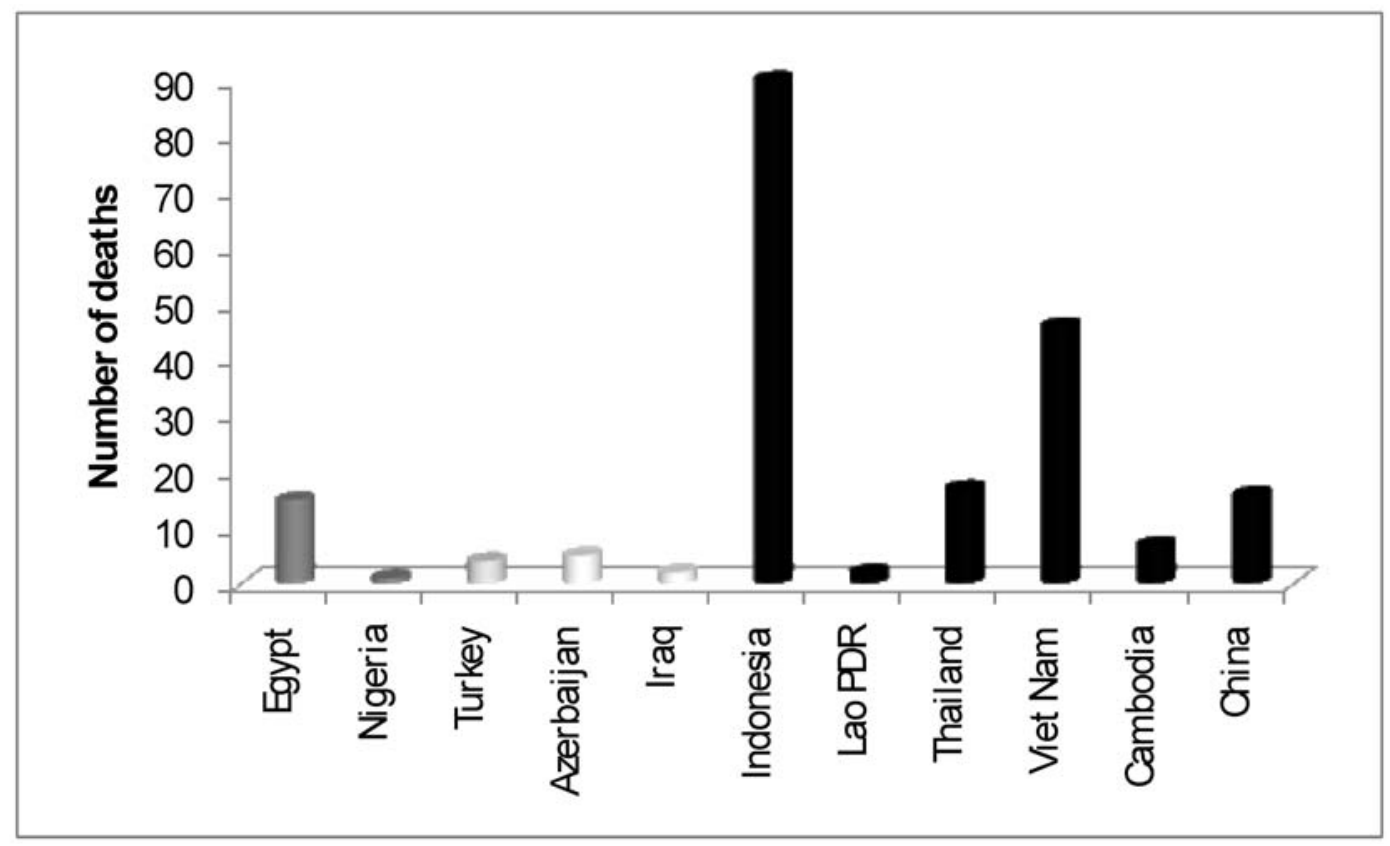

図 22003 年以降の H5N1 亜型のインフルエンザウイルスによる人の死亡数（出典 : WHO）

発生が続いており, 2007 年にも新たな発生が報告されて いる。タイとベトナムは, 過去に流行があったものの現在 までに沈静化できた国と考えられている。タイは摘発淘 汰, ベトナムはワクチンによる防疫を講じたことにより, 近年の発生数は激減している。しかしながら, ベトナムで はアヒルで散発的な発生が認められ, ワクチン接種が一 部で効果的に実施されていないという問題が指摘されて いる。迅速な撲滅に成功した国として, 日本, 韓国, マ
レーシアが挙げられている。日本ではH5N1 ウイルスに よる HPAI が 2004 年と 2007 年に, 韓国では 2003 年と 2006 年に発生しているが，両国ともに摘発淘汰を中心と する防疫措置により早期に撲滅している。その他, カンボ ジア，ミャンマー，ラオスなどについては散発的な発生が ある国として分析されている。

HPAI の発生リスクが高い国の要因として, (1) 防疫体 制が十分に整備されていない，(2)家きんの飼養密度が高 


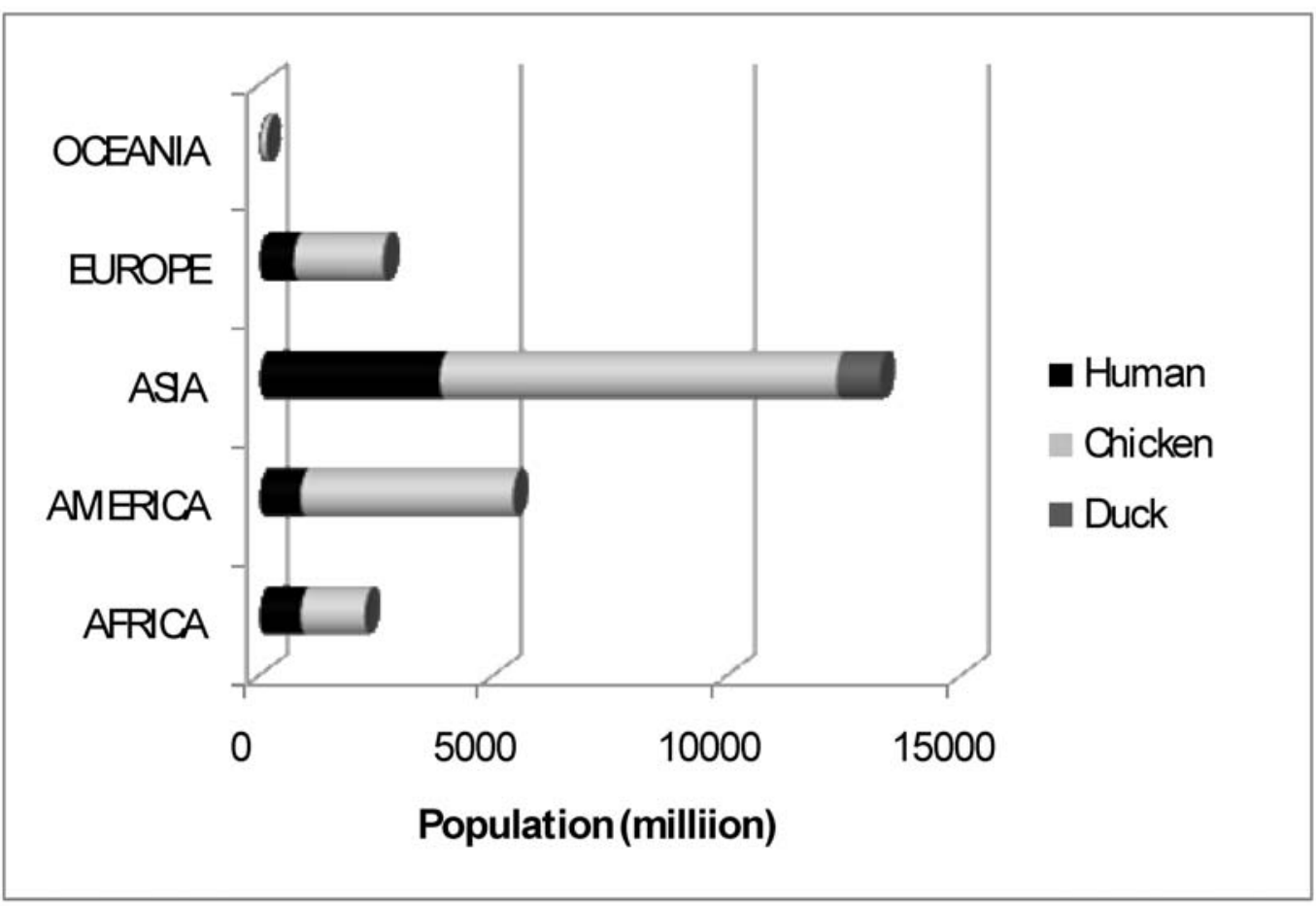

図 3 地域別の人口と鶏・アヒルの飼養羽数（出典 : 2004 年 FAO-STAT）

い, (3)バイオセキュリティが十分でない小規模の家きん 飼育農家が多い, (4)アヒルが多く飼養されている，(5)生 鳥マーケットを通じて家きんが流通している，6国境を 越えた人や物の不法な移動が認められる，(7)力モなどの 水きん類の渡り鳥が見られる, な゙が挙げられており，ア ジア地域の発生国には該当する項目が多い。

近年のアジア地域における HPAI の流行は, 公衆衛生 上の問題も相まって世界中の関心を集めている。このた め, 関係国はもちろんのこと, 日本も含め多くの国が人 的・物的支援を行うとともに, FAO, WHO, OIEなどの 国際機関も懸命にその沈静化に向けて協力を続けている。 その結果，多くの国では発生が減少する方向に向かって いるむのの，一部の国では散発的な発生が続き，また，一 度沈静化した後に再発生した国も認められている。アジア 地域ではインフラの整備状況などが国によってまちまち であり, 統一的な取組みを行うには難しい面がある。しか しながら，HPAI の撲滅は 1 ケ国の努力のみでは不可能 であり，地域全体としての対応が必須であると思われる。

\section{参考文献}

Domenech, J., Sims, L., Slingenbergh, J. and Lubroth, J. : Trends and dynamics of HPAI - epidemiological and animal health risks. Technical meeting on highly patho- genic avian influenza and human $\mathrm{H} 5 \mathrm{~N} 1$ infection, Rome, 2007, http://www.fao.org/docs/eims/upload//229342/ ah653e.pdf

FAO : The global strategy for prevention and control of $\mathrm{H} 5$ N1 highly pathogenic avian influenza. http://www.fao. org/docs/eims/upload//228807/a1145e.pdf

FAO : Guiding principles for highly pathogenic avian influenza surveillance and diagnostic networks in Asia. FAO expert meeting on surveillance and diagnosis of avian influenza in Asia. Bangkok, 2004.

Gleeson, L. J. : Control measures of Avian Influenza in AsiaPacific region. Proceedings in symposium on avian influenza in Asia and Africa, current situation and international measures. 26 Sep., 2007.

Petrini, A. : A global situation : HPAI outbreaks in poultrya synthesis of country reported to the OIE. Technical meeting on highly pathogenic avian influenza and human H5N1 infection, Rome, 2007, http://www.fao. org/docs/eims/upload//229338 /ah652e.pdf

Sims, L.D. et al. : Origin and evolution of highly pathogenic H5N1 avian influenza in Asia. Vet.Rec., 157, 159-164, 2005. 